\title{
Fate and transport of nutrients and pathogens applied to the land
}

T S Steenhuis

Cornell University, Ithaca, United States

Email:tss1@cornell.edu

Land application of biosolids and manure is generally considered beneficial. It adds nutrients and organic matter to the soil. It was especially beneficial early in the nineteen century when chemical fertilizers were expensive and in short supply. However, currently most agricultural soils have sufficient nutrients and application of additional nutrients may lead to ground water pollution or eutrophication of surface waters. In addition there is a concern about the offsite movement of pathogens

Once land applied, fate of the pathogens and nutrients depends partly on the hydrology of the watersheds. The hydrology of the watershed in turn depends on the depth of the restricting layer for water movement in the soil profile and the slope of the hillsides. Effectively managing and reducing nonpoint source pollution should take the hydrology and consequently the type of landscape into account.

In general, watersheds that have shallow restrictive layers have limited base flow during the summer, high peak flows during the wet periods and short residence times for water. The soils in these watersheds are periodically saturated due a perched water table on top of the restrictive layer. These saturated areas are the source of the surface runoff and can transport dissolved and particulate phosphorus and pathogens to the stream. At the same time these saturated areas are ideal for removal nitrate form the water by denitrification. Thus watersheds with shallow soils are characterized by low nitrate and elevated $\mathrm{P}$ concentrations in the surface waters. Although traditionally it was recommended that land applications should occur on the flattest land (located usually near the stream), current nutrient management practices on the watersheds with shallow restricting layers (such as the New York City drinking water source watersheds) consists of land application on the hillsides during wet times. Hillsides are unsaturated and rain water infiltrates before it exfiltrates down slope as interflow and becomes surface runoff in the saturated areas. In the New York City source watersheds, where nutrient management practices were implemented that avoided manure spreading on wet areas, dissolved phosphorus concentration have been decreased significantly.

When the depth of the restrictive layer increases, more water can be stored in the landscape, summer base flows increase and peak flows decrease. The watersheds with deep soils and no restrictive layers generally have a permanent ground water and saturation (if any) is limited to near stream areas. Preferential flow can transport small quantities of land applied chemicals rapidly to the permanent ground water. When these leached chemicals are toxic at low concentrations, (i.e., pathogens and pesticides), groundwater can become polluted and in some cases unsuitable for drinking water when more than $0.1 \%$ of the amount applied leaches. For other chemicals such as nitrate the amount transported via preferential flow paths is not sufficient to bring the groundwater concentration above the drinking water limit. In this case, nitrate concentrations in groundwater are exceeded when the nitrogen is applied in excess of crop needs. Phosphorus concentrations in groundwater are usually small because the phosphorus will be adsorbed to the soil. However, dissolved P concentration in tile lines can be elevated when P leaches via preferential flow path from the surface to the tile lines. Structural best management practices to prevent groundwater pollution due to both matrix and preferential flow are not generally available and the best way to prevent groundwater pollution is by applying less at times when groundwater is being recharged. 